UDC 633.358"324"

Original research paper

doi: 10.5937/AASer1947003M

Acta Agriculturae Serbica, Vol. XXIV, 47(2019); 3-11

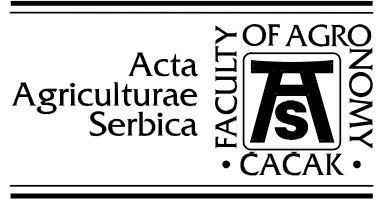

\title{
The first serbian cultivar of winter pea for grain, NS-Mraz
}

\author{
Vojislav Mihailović ${ }^{1}$, Sanja Vasiljević ${ }^{1}$, Đura Karagić ${ }^{1}$, \\ Branko Milošević $^{1}$, Vuk Radojevic ${ }^{2}$, Vera Popović ${ }^{1}$, Ivica Đalović ${ }^{1}$ \\ ${ }^{I}$ Institute of Field and Vegetable Crops, Maksim Gorki 30, 21000 Novi Sad, \\ Serbia \\ ${ }^{2}$ University of Novi Sad, Faculty of Agriculture, Department of Field and \\ Vegetable Crops, 21000 Novi Sad, Trg Dositeja Obradovića 8, Serbia \\ Corresponding author: vojislav.mihailovic@nsseme.com
}

\begin{abstract}
The first local cultivar of winter pea for grain, 'NS MRAZ', was developed by pedigree selection from the hybrid population created by crossing local populations and one French line of pea. The cultivar has a high seed yield potential, exceptional earliness and tolerance to low temperatures. Its average plant height is $75-85 \mathrm{~cm}$; it is of the afila type of pea, tolerant to lodging and of uniform maturity. Its genetic potential for seed yield is more than 7,000 kg ha-1, and it achieved an average seed yield of 5,110 kg ha-1 in three-year trials, while seed yield in production conditions was above $5,500 \mathrm{~kg} \mathrm{ha}^{-1}$. Thousand-grain weight is about $200 \mathrm{~g}$, which was the goal achieved in reducing the amount of seed per unit area. Protein yield ranged from 1,100 to $1,200 \mathrm{~kg} \mathrm{ha}^{-1}$.
\end{abstract}

Keywords: pea for grain, cultivar, yield, seed quality.

\section{Introduction}

Pea (Pisum sativum ssp.) is considered the oldest cultivated plant species. As the result of its biological traits, quite modest requirements in terms of growing conditions and great genetic diversity and adaptability, it is widespread on all continents. There are winter and spring pea forms, intended for different uses (as dry seed or fodder in the form of fresh biomass, hay, haylage and silage in mixed 
cropping with small grains). The Institute of Field and Vegetable Crops Novi Sad has been involved in pea breeding and selection activities for more than 60 years and, as a result, numerous cultivars of winter pea for fodder and spring pea for fodder and grain have been developed. However 'NS MRAZ' is the first winter pea cultivar intended for grain production. Pea cultivars for grain production have a modified stem architecture, reach a height of 60 to $85 \mathrm{~cm}$, develop closely spaced nodes and shortened internodes, making the stem firmer and more resistant or at least tolerant to lodging. They have normal or afila-type leaves, with high potential for seed yield and excellent seed quality, and they exhibit early maturity and winter hardiness.

Considering the above mentioned, the aim of this paper was to develop a winter pea cultivar for grain, with traits defined in the designed ideotype.

\section{Material and Methods}

Researchers of the Institute of Field and Vegetable Crops have collected a great number of cultivars, lines and populations of pea from all over the world since the 1980s. This collection serves as a basis for pea breeding and selection activities. Through hybridisation and combination breeding using different methods, a large number of lines and cultivars with divergent traits have been developed. Apart from direct crossbreeding, a great number of back crossings have also been performed in order to introduce genes responsible for the expression of specific traits. In preliminary and comparative trials, lines showing promising characteristics in terms of yield, seed quality, early maturity and resistance to low temperatures have been selected. One such line, under the working title L-574, has been submitted to the Commission for the Registration of Plant Varieties of the Ministry of Agriculture, Forestry and Water Management of the Republic of Serbia, for further testing and registration. A trial was set up at the trial field of the Institute of Field and Vegetable Crops during three years (from 2010 to 2012) to study seed yield, overwintering and morphological characteristics. Chemical and technological traits of the seed were analysed at the Institute for Forage Crops in Kruševac.

\section{Results and Discussion}

In November 2011, the Ministry of Agriculture, Trade, Forestry and Water Management, Department of Plant Variety Registration registered the first Serbian cultivar of winter pea for grain - 'NS-Mraz' under the Decision No. 320-0412448/2/2009-2011 of 8 November 2011.

Winter pea cultivar 'NS-Mraz' was developed by crossing local populations and a French line of protein pea, which proved to be resistant to low temperatures under the agroenvironmental conditions of the Republic of Serbia. From the hybrid population developed by crossing such two lines, progeny exhibiting marked 
resistance to low temperatures, early maturity and high seed yields were gradually selected. This process lasted for many years, because it was necessary to stabilise the gene responsible for resistance to low temperatures, while retaining other desirable properties - earliness, stem habitus, yield and seed quality. One of the selected lines that proved promising in preliminary and comparative trials was given the working title L-574. This line was tested together with the most widespread spring cultivars of pea for grain in Serbia, i.e. the Novi Sad cultivars 'NS-Junior', 'Jezero' and 'Javor', as well as Czech cultivars 'Bohatir', 'Tirkis' and 'Menhir'. Since it showed good results, it was submitted to the Commission for the Registration of Plant Varieties for further testing.

'NS-Mraz' possesses the usual traits of protein pea cultivars, i.e. cultivars for dry seed production. The stem is very firm and tolerant to lodging, due to the increased presence of mechanical tissue, reaching a height between 60 and $80 \mathrm{~cm}$. The leaf is of the afila type with leaves turned into tendrils. This results in the interconnection of plants in early stages of growth and development, which makes the crop highly resistant to lodging until full maturity. Stipules are very large and have a significant role in plant photosynthesis. Mature seed is green to yellow. Thousand-grain weight is about $200 \mathrm{~g}$ or usually less, which results in less expensive sowing compared to spring cultivars of protein pea. The cultivar 'NSMraz' overwinters with more than $90 \%$ of seedlings, during the winter period, depending on frost severity, frost duration, presence or absence of snow, etc. This cultivar has been widely produced for several years now in Serbia and abroad, and proved its excellent winter hardiness.

During 2010, 2011 and 2012 at the trial fields of the Institute of Field and Vegetable Crops at Rimski Šančevi, a trial was set up in order to determine seed yield, evaluate overwintering and analyse seed quality of the newly released cultivar 'NS MRAZ'.

Table 1. Seed yield of winter pea for grain, 'NS-Mraz' $\left(\mathrm{kg} \mathrm{ha}^{-1}\right)$

\begin{tabular}{|c|c|c|c|c|c|c|c|}
\hline Locality & Year & \multicolumn{4}{|c|}{$\begin{array}{l}\text { Seed yield } \\
\left(\mathrm{kg} \mathrm{ha}^{-1}\right)\end{array}$} & $\begin{array}{l}\text { Average } \\
\left(\mathrm{kg} \mathrm{ha}^{-1}\right)\end{array}$ & $\begin{array}{l}\text { Protein yield } \\
\left(\mathrm{kg} \mathrm{ha}^{-1}\right)\end{array}$ \\
\hline \multirow{5}{*}{$\begin{array}{l}\text { Novi } \\
\text { Sad }\end{array}$} & \multirow[b]{3}{*}{2010} & \multicolumn{4}{|c|}{ Replications } & \multirow[b]{3}{*}{4,740} & \multirow[b]{3}{*}{1,087} \\
\hline & & I & II & III & IV & & \\
\hline & & 4,910 & 4,570 & 4,725 & 4,756 & & \\
\hline & \multirow{2}{*}{$\begin{array}{l}2011 \\
2012 \\
\end{array}$} & 5,100 & 5,372 & 4,911 & 5,073 & \multirow{2}{*}{$\begin{array}{l}5,114 \\
5,476\end{array}$} & \multirow{2}{*}{$\begin{array}{l}1,172 \\
1,255\end{array}$} \\
\hline & & 5,429 & 5,636 & 5,297 & 5,541 & & \\
\hline \multirow{4}{*}{ LSD } & & & & & & 5,110 & 1,171 \\
\hline & 0,05 & \multicolumn{4}{|l|}{137} & & \\
\hline & 0,01 & \multicolumn{4}{|l|}{198} & & \\
\hline & $\mathrm{CV}$ & \multicolumn{4}{|l|}{109} & & \\
\hline
\end{tabular}


The average seed yield from four replications was the lowest in 2010 and amounted to $4740 \mathrm{~kg} \mathrm{ha}^{-1}$, which is statistically significantly lower than in 2011 $\left(5114 \mathrm{~kg} \mathrm{ha}^{-1}\right)$ and $2012\left(5476 \mathrm{~kg} \mathrm{ha}^{-1}\right)$. Therefore, the average seed yield for all three years of testing at this locality was $5110 \mathrm{~kg} \mathrm{ha}^{-1}$ at the average density of 1.1 million plants per hectare. Seed yields across testing years were uniform, which clearly shows the stability of this cultivar (Table 1).

Seed yields higher than $5000 \mathrm{~kg} \mathrm{ha}^{-1}$ can be considered very good although the genetic potential of this cultivar is above $7000 \mathrm{~kg} \mathrm{ha}^{-1}$. During all three testing years, in October, after plant emergence, the number of plants was determined and compared to the number of plants in spring, after overwintering. The comparison showed that winter killing did not occur in any of the three years, which is an important indicator of winter hardiness of this cultivar in Serbian agroenvironmental conditions. In addition to good resistance to low temperatures, another significant advantage of 'NS-Mraz' is its earliness, which was one of the goals of its development. Flowering begins in early or mid-April, depending on weather conditions, which makes it able to avoid the strongest attack of pea beetle naturally. In years when the growing season started earlier, 'NS-Mraz' was completely mature in late May, while it is common for 'NSMraz' to be fully mature for combine harvesting during the last week of May or early June. Anyhow, this cultivar is at least seven days earlier than the earliest barley cultivars. Therefore, most producers that grow pea and mostly own only one combine harvester during harvest do not have to choose which crop to harvest first, pea or barley, or pea or wheat. They can grow and harvest all three crops: pea, barley and wheat, one after another.

Seed yields of 'NS-Mraz' are averagely higher than $4000 \mathrm{~kg} \mathrm{ha}^{-1}$ with the yield potential of above $7000 \mathrm{~kg} \mathrm{ha}^{-1}$, with the use of necessary cultivation practices common for pea and in favourable agroenvironmental conditions.

Table 2. Morphological traits and 1,000-grain weight of winter pea cultivar 'NSMraz'

\begin{tabular}{|l|c|c|c|c|c|}
\hline Locality & Year & $\begin{array}{c}\text { Plant height } \\
(\mathrm{cm})\end{array}$ & $\begin{array}{c}\text { Height to first } \\
\text { pod }(\mathrm{cm})\end{array}$ & $\begin{array}{c}\text { Number of } \\
\text { pods per } \\
\text { plant }\end{array}$ & $\begin{array}{c}1,000- \\
\text { grain } \\
\text { weight }(\mathrm{g})\end{array}$ \\
\hline Rimski & 2010 & 85 & 52 & 12 & 194 \\
Šančevi & 2011 & 72 & 47 & 9 & 196 \\
& 2012 & 77 & 46 & 14 & 201 \\
\hline Average & & 78 & 48 & 12 & 197 \\
\hline
\end{tabular}

Plant height in pea is a very significant quantitative property, conditioned by a large number of genes localised at different chromosomes (Kliša, 1988; Mihailović, 1994). This modified stem architecture is the result of shortened 
internodes and closely spaced nodes, leaves reduced to tendrils (afila leaf type), which makes the plant more resistant to lodging.

The average plant height of 'NS-Mraz' for all three testing years was $78 \mathrm{~cm}$, and it ranged from 72 to $85 \mathrm{~cm}$, which indicates very small deviations by year. Plant height during the first pod formation was about $50 \mathrm{~cm}$, which is of importance for mechanised harvest. The average number of pods per plant was 12, and ranged from 9 to 14 . This cultivar typically forms more than 20 pods per plant in favourable agroenvironmental conditions, which shows high yield potential (Table 2). Numbers of pods per plant and seeds per pod as well as 1000 -grain weight have the largest effect on seed yield (Hanglidin, 1972; Petrik, 1976). Similar results were obtained by Mihailović (1990), Ćupina (1995) and Mikić (2014).

Seed size in pea is a cultivar trait and depends on its purpose (biomass or grain), and ranges from 80 to $400 \mathrm{~g}$. There are several classifications of pea cultivars depending on seed size, but the most widespread is the classification by Makasheva (1973), Mihailović et al. (2004) into: a) small seed cultivars, with 1000 -grain weight not exceeding $150 \mathrm{~g}$; b) medium large seed cultivars, with 1000 -grain weight ranging from 150 to $250 \mathrm{~g}$; and c) large seed cultivars, with 1000 -grain weight exceeding $250 \mathrm{~g}$. During the development of this cultivar, special attention was paid to 1000 -grain weight, because it directly affects the quantity of seed for sowing, and consequently production costs, and is also directly proportional to seed yield. Hence, one of the goalswas to develop a cultivar with 1000 -grain weight up to 200 grams, which we achieved. Across three years of testing, 1000 -grain weight was 197 grams on average and ranged from $194 \mathrm{~g}$ to $201 \mathrm{~g}$ (Table 2). Our results confirmed previous studies showing that 1 000-grain weight is a highly heritable trait (Kliša, 1988; Mikić, 2012).

Table 3. Chemical and technological traits of winter pea cultivar 'NS-Mraz'

\begin{tabular}{|l|l|l|l|l|l|l|l|l|}
\hline Locality & Replications & $\begin{array}{c}\text { Crude } \\
\text { fibre }\end{array}$ & Fats & $\begin{array}{c}\text { Crude } \\
\text { ash }\end{array}$ & NFE & ADF & NDF & Proteins \\
\hline Kruševac & I & 16.76 & 3.02 & 11.15 & 45.87 & 32.08 & 46.34 & 23.20 \\
\cline { 2 - 9 } & II & 19.97 & 2.68 & 11.56 & 45.64 & 32.94 & 45.43 & 23.15 \\
\cline { 2 - 9 } & III & 17.23 & 2.72 & 11.45 & 45.93 & 32.42 & 45.44 & 22.67 \\
\cline { 2 - 9 } & IV & 17.10 & 3.09 & 11.46 & 45.52 & 32.74 & 46.02 & 22.83 \\
\cline { 2 - 9 } & V & 17.20 & 2.74 & 11.69 & 45.61 & 32.06 & 45.52 & 22.76 \\
\hline Average & & 17.06 & 2.85 & 11.47 & 45.72 & 32.45 & 45.75 & 22.93 \\
\hline
\end{tabular}

In order to determine the nutritional value of pea seeds in farm animal nutrition, their chemical and technological traits were analysed. The percentage of crude protein in pea seeds varied from $18 \%$ to $36 \%$, while its range in the majority 
of cultivars was between $21 \%$ and $25 \%$ (Mihailović, 1994). Crude protein content in 'NS-Mraz' was around $23 \%$, but the biological value, i.e. the amino acid composition of proteins, was highly important as well (Vetrova et al., 1982; Ćupina, 1997). Bond and Smith (1988) highlighted the high content of the essential amino acid lysine and the low content of sulphuric amino acids (methionine and tryptophan) in pea seeds, which have strong nutritional effects. ADF content was 32.45 and NDF 45.75 (Table 3). Total protein yield per unit area is definitely the most practical indicator. It is the result of seed yield and protein percentage in the seed. Slamena (1984) believed that the quality protein yield of thousand kilograms per hectare is a success, which can be achieved by the seed yield of $4000 \mathrm{~kg} \mathrm{ha}^{-1}$ and protein content of $25 \%$. The tested cultivar had the average three-year protein yield of $1171 \mathrm{~kg} \mathrm{ha}^{-1}$, and protein levels ranged from $1087 \mathrm{~kg} \mathrm{ha}^{-1}$ in 2010 to $1255 \mathrm{~kg} \mathrm{ha}^{-1}$ in 2012, when the highest seed yield was achieved (Table 1). The results confirmed the high yield potential of this winter pea cultivar for grain even in production conditions.

Table 4. Processed seed yield of winter pea cultivar 'NS-Mraz' in 2016

\begin{tabular}{|l|c|c|}
\hline Producer & Area (ha) & $\begin{array}{c}\text { Processed seed yield } \\
\left(\mathrm{kg} \mathrm{ha}^{-1}\right)\end{array}$ \\
\hline Institute of Field and Vegetable Crops, Novi Sad & 15 & 5,748 \\
\hline PP Feketić, Feketić & 10 & 5,652 \\
\hline Global Seed, Čurug & 116 & 4,100 \\
\hline
\end{tabular}

Average processed seed yield in production areas in 2016 was above $5.5 \mathrm{t} \mathrm{ha}^{-1}$, and it was $4100 \mathrm{~kg} \mathrm{ha}^{-1}$ in Global Seed in Čurug in organic production. Combine harvesting of pea in Feketić started on 16 June and ended on 19 June in Rimski Šančevi. It is clear that sowing was later than usual, due to abundant precipitation in that year of production (Milošević, 2017). A significant amount of straw (rich in proteins) remains after an early harvest of pea cultivar 'NS-Mraz', which can be additionally used as animal feed. It should be noted that, after the early harvest of this cultivar in late May or early June, there is enough time for sowing another crop. It is possible to subsequently sow forage sorghum, Sudan grass, some vegetable crops or silage maize, thus increasing the level of utilization of arable land.

\section{Conclusions}

Based on the research results, the following conclusions were made:

- The newly released cultivar of winter pea for grain, 'NS-Mraz', has high seed yield potential. In a three-year trial, dry seed yield ranged from 4740 to $5476 \mathrm{~kg} \mathrm{ha}^{-1}$, while protein yield ranged from 1087 to $1255 \mathrm{~kg}$ $\mathrm{ha}^{-1}$; 
- The cultivar is of the afila type of leaf, $75-85 \mathrm{~cm}$ in height, winter hardy, very early maturing;

- Thousand-grain weight is up to $200 \mathrm{~g}$, which indicates that the seed is medium large in size, while crude protein content in the seed ranges from $23 \%$ to $25 \%$.

- 'NS-Mraz' has already been widely produced in both Serbia and abroad, and its seed yields of about $6 \mathrm{tha}^{-1}$ make it a promising cultivar.

\section{Acknowledgment}

This study is part of project TR 31024 "Increasing market significance of forage crops by breeding and optimizing seed production technology", financed by the Ministry of Education, Science and Technological Development of the Republic of Serbia, 2011-2019.

\section{References}

Bond D. A., Smith D. B. (1988): Potential for improving the nutritional quality of grain legumes by breeding. Hodowla roslin aklimatyzacija i nasiennictwo, 1/2, 32 .

Ćupina B. Erić P. Mihailović V. (1995): Produktivnost i kvalitet zrna jarog stočnog graška u zavisnosti od broja biljaka. Zbornik radova, Institut za ratarstvo i povrtarstvo, Novi Sad, 23: 473-484.

Ćupina B. (1997): Dinamika formiranja prinosa i kvaliteta stočnog graška (Pisum sativum L.). Doktorska disertacija, Poljoprivredni fakultet, Novi Sad.

Hanglidin V. N. (1972): Dostiženjija i zadaci selekciji garoha v SSSR-u. Selekcija i semenovodstvo, 6 .

Kliša A. I. (1988): Korelacija urožaja goroha s elementami produktivnosti. Selekcija i semenovodstvo, 3: 15-16.

Makaševa R. H. (1973): „Goroh“. Kolos, vol. 219-306, Lenjingrad.

Mikić A. Ćupina B. Mihailović V. Krstić Đ. Đorđević V. Perić V. Srebrić M. Antanasović S. Marjanović J., Kobiljski B. (2012). Forage legume intercropping in temperate regions: models and ideotypes, In: Lichtfouse E (ed.) Sustainable Agriculture Reviews 11, Springer Science + Business Media, Dordrecht, the Netherlands: $161-182$.

Mikić A. (2014): Genetička analiza hibridnih potomstava proteinskog (Pisum sativum L.) i mrkožutog (Pisum fulvum Sm) graška. Doktorska disertacija, Poljoprivredni fakultet, Novi Sad.

Milošević B. (2017): Kvantitativne i kvalitativne promene proteinskog graška (Pisum sativum L.) od formiranja do žetvene zrelosti zrna. Doktorska disertacija. Poljoprivredni fakultet, Novi Sad.

Mihailović V. (1990): Nasleđivanje kvantitativnih svojstava kod jarog stočnog graška. Magistarski rad, Poljoprivredni fakultet, Novi Sad.

Mihailović V. (1994): Genetička analiza komponenti prinosa zrna i žetvenog indeksa graška (Pisum sativum L.). Doktorska disertacija, Poljoprivredni fakultet, Novi Sad. 
Mihailović V., Erić P., Karagić Đ., Milić, D., Mikić A. (2004): Prinos i komponente prinosa zrna stočnog graška u zavisnosti od tipa lista. Acta Agriculturae Serbica, IX:17 (special issue): 67-71.

Petrik M.I. (1976): Napravljenjia i rezuljtati selekcii goroha na korm. Selekcija i semenovodstvo, No. 1.

Slamena Z. (1984): Vyskum a využitie dedičnosti znakov productivity struktovin hrahus siateho (Pisum sativum L.). Sprava za časovu etapu, VURV_ŠS., 67 s, Horna Streda

Vetrova E. H., Golban N.M., Korobko V.A. (1982): Zernobobovie kuljturi. Kišinjov. 


\title{
PRVA SRPSKA SORTA OZIMOG GRAŠKA ZA ZRNO, NS-MRAZ
}

\author{
Vojislav Mihailović ${ }^{1}$, Sanja Vasiljević ${ }^{1}$, Đura Karagić ${ }^{1}$, \\ Branko Milošević ${ }^{1}$, Vuk Radojević ${ }^{2}$, Vera Popović ${ }^{1}$, Ivica Đalović ${ }^{1}$ \\ ${ }^{1}$ Institut za ratarstvo i povrtarstvo, Maksima Gorkog 30, 21000 Novi Sad, Srbija \\ ${ }^{2}$ Univerzitet u Novom Sadu, Poljoprivredni fakultet, Novi Sad, Trg. D. \\ Obradovića 8, 21000 Novi Sad, Srbija
}

\section{Rezime}

Prva domaća sorta ozimog graška za zrno, NS MRAZ, nastala je pedigre metodom selekcije iz hibridne populacije nastale ukrštanjem domaćih populacija i jedne francuske linije graška. Sorta se odlikuje visokim potencijalom rodnosti zrna, izuzetnom ranostasnošću i otpornošću na niske temperature. Prosečna visina stabljike je 75 do $85 \mathrm{~cm}$, afila tipa, tolerantna na poleganje i ujednačenog sazrevanja. Genetički potencijal za prinos zrna je iznad $7000 \mathrm{~kg} \mathrm{ha}^{-1}$, a u trogodišnjim ogledima ostvarila je prosečan prinos zrna od $5110 \mathrm{~kg} \mathrm{ha}^{-1}$, dok je u proizvodnim uslovima prinos semena bio iznad $5500 \mathrm{~kg} \mathrm{ha}^{-1}$. Masa $1000 \mathrm{zrna}$ je oko 200 grama, što je i bio cilj, kako bi se smanjila količina semena po jedinici površine. Prinos proteina kretao se od 1100 do $1200 \mathrm{~kg} \mathrm{ha}^{-1}$.

Ključne reči: grašak za zrno, sorta, prinos, kvalitet zrna. 